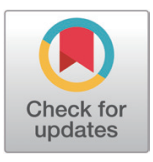

Received: Aug 31, 2020

Revised: Oct 10, 2020

Accepted: Nov 4, 2020

*Corresponding author Jungheun $\mathrm{Ha}$

Department of Food Science and Nutrition, Dankook University, Cheonan 31116, Korea.

Tel: +82-41-550-3479

E-mail: ha@dankook.ac.kr

Jungseok Choi

Department of Animal Science, Chungbuk National University,

Cheongju 28644, Korea

Tel: +82-43-261-2551

E-mail: jchoi@chungbuk.ac.kr

Copyright $\odot 2021$ Korean Society of Animal Sciences and Technology. This is an Open Access article distributed under the terms of the Creative Commons Attribution Non-Commercial License (http:// creativecommons.org/licenses/bync/4.0/) which permits unrestricted non-commercial use, distribution, and reproduction in any medium, provided the original work is properly cited.

ORCID

Jaeyoung Kim

https://orcid.org/0000-0002-2847-1731

Meyungok Jung

https://orcid.org/0000-0003-4578-4569

Sangkeun Jin

https://orcid.org/0000-0002-8983-5607

Hyunseok Seo

https://orcid.org/0000-0003-0962-2255

Jungheun $\mathrm{Ha}$

https://orcid.org/0000-0001-5282-531X

\section{The effect of boiled feed on trace elements of longissimus dorsi muscle in Hanwoo steers}

\author{
Jaeyoung Kim ${ }^{1}$, Meyungok Jung ${ }^{1,2}$, Sangkeun $\mathrm{Jin}^{3}$, Hyunseok Seo', \\ Jungheun $\mathrm{Ha}^{4 *}$ and Jungseok Choi ${ }^{1 *}$ \\ ${ }^{1}$ Department of Animal Science, Chungbuk National University, Cheongju 28644, Korea \\ ${ }^{2}$ Foundation of Agriculture Technology Commercialization \& Transfer, Jeonju 54667, Korea \\ ${ }^{3}$ Department of Animal Resources Technology, Gyeongnam National University of Science and \\ Technology, Jinju 52725, Korea \\ ${ }^{4}$ Department of Food Science and Nutrition, Dankook University, Cheonan 31116, Korea
}

\begin{abstract}
Boiled feed is obtained by mixing and boiling agricultural by-products such as rice straw, rice bran, and bean curd with grains. The study explored the change in fatty acid, free amino acid, nucleotide, mineral, cholesterol, myoglobin and collagen of longissimus dorsi muscle in Hanwoo steers fed with boiled feed. Forty steers, 20 heads per group, were divided into two groups: a control group and a boiled feed group. The steers were raised for 10 months. The boiled feed group was enriched with palmitoleic acid, oleic acid, arachidonic acid and unsaturated fatty acids compared with the control group. There were no significant differences in amino acid and nucleic acid composition between the two groups. The boiled feed group contained higher levels of iron and manganese in the boiled feed group compared with the control group. The total cholesterol level was significantly increased, whereas calorie levels, myoglobin and collagen composition showed no differences. As the supply of boiled feed increases the content of fatty acids, unsaturated fatty acids and minerals related to flavor, it should be a feed that leads to the production of high-quality beef.
\end{abstract}

Keywords: Boiled feed, Longissimus dorsi muscle, Fatty acids, Amino acids, Nucleic acids, Trace substance

\section{INTRODUCTION}

The cost of cattle feed exceeds $70 \%$ of the total production cost in the Korean beef industry [1,2]. International grain prices have an important influence on the cost of Korean livestock industry because most feed is imported. The recent increase in feed cost has been attributed to the use of feed materials in bioenergy production and reduced export of feedstock by the major grain-producing countries. Higher import prices of feedstock will weaken the competitive position of the Korean beef industry in the global market [3]. To minimize the feed expenditure and enhance productivity, the cattle are provided with the boiled feed, which is used traditionally in Korea.

The boiled feed was provided to Hanwoo steers in Korea before it was used to improve beef cattle. The boiled feed comprises a mixture of rice straw, by-products such as rice bran, corn husk, bean-curd, 
Jungseok Choi

https://orcid.org/0000-0001-8033-0410

Competing interests

No potential conflict of interest relevant to

this article was reported.

Funding sources

This work was supported by a grant $(715003$ 07) from the Research Center for Production Management and Technical Development for High Quality Livestock Products through Agriculture, Food and Rural Affairs Convergence Technologies Program for Educating Creative Global Leader, Ministry of Agriculture, Food and Rural Affairs. This work also was supported by the National Research Foundation of Korea (NRF) grant funded by the Ministry of Education (No. 2020R1A4A1017552, 2020R1G1A1006498).

\section{Acknowledgements}

Not applicable.

Availability of data and material Upon reasonable request, the datasets of this study can be available from the corresponding author.

Authors' contributions

Conceptualization: Jung M, Choi J.

Data curation: Kim J.

Formal analysis: Kim J, Jung M.

Methodology: Kim J, Seo H.

Software: Jin S, Ha J.

Validation: Jin S.

Investigation: Jung M.

Writing - original draft: Kim J, Jung M.

Writing - review \& editing: Jin S, Ha J, Choi J.

Ethics approval and consent to participate This article does not require IRB/IACUC approval because there are no human and animal participants. dried radish leaves, sesame dregs with grains, which are boiled in a big cauldron [4]. The boiled feed is inexpensive with readily available raw materials compared with the general feed blend. Therefore, the supply of the boiled feed is expected to shelve the production cost. The equipment that automatically facilitates throwing, agitating, heating and discharging of different ingredients is readily available commercially in Korea [5].

In the recent studies, it was reported that the boiled feed was faster degraded and absorbed in the rumen than a general feed, and the cattle fed with the boiled feed grew rapidly in lean meat content [4,6]. Different feed ingredients are thought to have effects on meat quality as well as meat quantity. However, there was very rare about the research of the boiled feed in spite that it was widely supplied to beef cattle in Korea. The objective of this work is to investigate the effect of boiled feed on the composition of minor substances in Hanwoo steer's longissimus dorsi muscle.

\section{MATERIALS AND METHODS}

\section{Animal management and feeds}

Forty Hanwoo steers (22 months old) were purchased from Hanwoo farms in Chungnam Korea and raised for 11 months from February 2016 to December 2016 including the acclimation period for a month. The experimental animals were divided into two groups of 20 each: control and boiled feed. The control group was fed on non-boiled feed, and the boiled feed group was treated with boiled feed. The formula of feed mixture is shown in Table 1. Each group was randomly allotted 4 heads in a $790 \mathrm{~cm} \times 800 \mathrm{~cm}$ square of cattle pen and repeated 5 times. The water and minerals were provided arbitrarily, and the feed was given twice a day at 8 and 16 o'clock. The feed was purchased from Easy Farms (Cheonan, Korea), and the by-products including rice bran, rice straw and barley straw was utilized as roughage (Table 1). To prepare the boiled feed, raw feed was inserted to cauldron and the same weight of water was added to a cauldron. The feed was heated at $135^{\circ} \mathrm{C}$ for $6 \mathrm{~h}$, whereas the control feed was unheated. The ingredients of the two types of feed were listed in Table 2. The feed ingredient was measured by AOAC method [7]. The water content of feed was analyzed based on the difference in weight before and after drying at $105^{\circ} \mathrm{C}$ for $8 \mathrm{~h}$. The sample was burnt to ash at $550^{\circ} \mathrm{C}$ for $12 \mathrm{~h}$ and the mineral content was estimated. The crude protein was measured with Kjeldahl method, and the crude fat content was estimated with soxhlet method. The contents of neutral detergent fiber (NDF) and acid detergent fiber were measured using Van Soest's methods [8].

\section{Trace substances of longissimus dorsi muscle}

The animals were sacrificed and cooled at $0^{\circ} \mathrm{C}$ for 18 to $24 \mathrm{~h}$. The longissimus dorsi muscle was deboned, separated, shaped, vacuum-sealed, and stored at $4^{\circ} \mathrm{C}$.

To measure the fatty acid composition of longissimus dorsi muscle, a $50 \mathrm{~g}$ sample was

Table 1. Formulation of feed mixture

\begin{tabular}{lccc}
\hline \multirow{2}{*}{ Items } & \multicolumn{2}{c}{ Formulation } & $\begin{array}{c}\text { Intake yield } \\
(\mathbf{k g} / \mathbf{h} / \mathbf{d})^{\mathbf{1})}\end{array}$ \\
\cline { 2 - 3 } & Weight $\mathbf{( k g )}$ & Ration $(\%)$ & 4.29 \\
Total mixed ratio & 1,500 & 51 & 0.86 \\
Rice bran & 300 & 10 & 3.00 \\
Rice straw & 1,050 & 36 & 0.29 \\
Barley straw & 100 & 3 & 8.44 \\
\hline \multicolumn{1}{c}{ Total } & 2,950 & 100 & \\
\hline
\end{tabular}

\footnotetext{
${ }^{1)}$ (kg/head/day): daily intake per a head.
} 
Table 2. Chemical composition of experimental feeds

\begin{tabular}{lcc}
\hline \multicolumn{1}{c}{ Items } & Control & Boiled feed \\
\hline Moisture (\%) & 11.6 & 35.9 \\
Crude fat (\%) & 3.0 & 3.8 \\
Crude protein (\%) & 8.5 & 8.5 \\
Crude fiber (\%) & 18.1 & 10.0 \\
Ash (\%) & 7.2 & 7.0 \\
Calcium (\%) & 0.4 & 0.5 \\
Phosphorus (\%) & 0.3 & 0.5 \\
NDF & 44.6 & 27.1 \\
ADF & 24.2 & 15.2 \\
\hline
\end{tabular}

NDF, neutral detergent fiber; ADF, acid detergent fiber.

homogenized in $150 \mathrm{~mL}$ organic solvent (chloroform : methanol $=2: 1 \mathrm{vol} / \mathrm{vol}$ ) and the lipids were isolated. The lipid extract was concentrated at $50^{\circ} \mathrm{C}-55^{\circ} \mathrm{C}$ after removing moisture with anhydrous sodium sulfate, followed by the addition of $1 \mathrm{~mL}$ of $0.5 \mathrm{~N} \mathrm{NaOH}$ to the concentrated lipid extract and heating at $10{ }^{\circ} \mathrm{C}$ for $20 \mathrm{~min}$. The mixture was treated with $2 \mathrm{~mL}$ of BF3-methanol and $\mathrm{NaCl}-$ heptane solution [9]. Finally, the fatty acids were measured with gas chromatography (Agilent Technologies, Santa Clara, CA, USA). The gas chromatography conditions for analysis of fatty acids were as follows; the column was an Omegawax 205 fused-silica bond capillary column (30 m, $0.3 \times 2 \mathrm{~mm}$ I.D., $0.25 \mu \mathrm{m}$ film thickness), the detector was a flame ionization detector, the mobile phase was $99.99 \%$ nitrogen gas and $1 \mathrm{~mL} / \mathrm{min}$ column influx rat.

The free amino acids were analyzed by homogenizing $0.5 \mathrm{~g}$ longissimus dorsi muscle in $1.5 \mathrm{~mL}$ distilled water, followed by centrifugation at $15,000 \times \mathrm{g}$ and $4^{\circ} \mathrm{C}$ for $15 \mathrm{~min}$. The supernatant was diluted 10 -fold with ethanol and centrifuged at $13,000 \times \mathrm{g}$ and $4^{\circ} \mathrm{C}$ for $10 \mathrm{~min}$. Free amino acid content was analyzed with LC/MS/MS (Xevi TQ-S, Waters, Milford, MA, USA).

For the analysis of nucleic acids, $0.3 \mathrm{~g}$ longissimus dorsi muscle was added to $5 \mathrm{~mL} 0.5 \mathrm{M}$ perchloric acid and centrifuged at $9,200 \times \mathrm{g}$ and $4^{\circ} \mathrm{C}$ for $5 \mathrm{~min}$. After the addition of $0.25 \mathrm{~mL}$ of 2.1 $\mathrm{M} \mathrm{KHCO}_{3}$ to $1 \mathrm{~mL}$ supernatant, it was centrifuged at $9,200 \times \mathrm{g}$ and $4^{\circ} \mathrm{C}$ for $5 \mathrm{~min}$ and filtered with a $0.45 \mu \mathrm{m}$ syringe filter. Standard reference materials including hypoxanthine, uridine, inosine, guanosine monophosphate, adenosine monophosphate, adenosine diphosphate, and inosine monophosphate (IMP) were purchased from Sigma-Aldrich (St. Louis, MO, USA). Nucleic acids were analyzed with High Performance Liquid Chromatography (HPLC, Shiseido, Tokyo, Japan).

Mineral contents of longissimus dorsi muscle were estimated by AOAC method [7]. An appropriate amount of beef sample was burnt to ashes with an electric muffle furnace (JSMF270T, JS Research, Gongju, Korea) at $600^{\circ} \mathrm{C}$ for $12 \mathrm{~h}$. The ashes were dissolved in an acidic solution $\left(\mathrm{HCl}: \mathrm{H}_{2} \mathrm{O}=1: 1\right)$ overnight and the solution was filtered with a Whatman No. 6 filter paper. The absorbance was measured via atomic absorption spectrometry (ICP Spectrophotometer, Spectroflame, Spectro, Germany) and the mineral content was calculated using the following formula.

Mineral content $(\mathrm{mg} / \mathrm{kg})=\frac{\text { Sample absorbance } / 1 \mathrm{ppm} \text { standard absorbance } \times \text { dilution rate }}{\text { Sample weight }(\mathrm{g}) \times 10^{6}} \times 100$

The cholesterol content of the longissimus dorsi muscle was measured via the following procedure. Five grams of beef sample were added to the solution mixture containing $8 \mathrm{~mL}$ of $60 \% \mathrm{KOH}$ and $40 \mathrm{~mL}$ of alcohol solution (ethanol : methanol : isopropyl alcohol = $90: 5: 5$ ), and was saponified 
at $100^{\circ} \mathrm{C}$ for $1 \mathrm{~h}$. The saponified matter was concentrated with benzene and $\mathrm{KOH}$ in a separating funnel and was mixed with 1,000 ppm squalene. The cholesterol content was analyzed via gas chromatography (HP-7890A, Agilent Technologies). The column that was made of a fused-silica bond capillary (30 m, $0.22 \times 0.32 \mathrm{~mm}$, nonpolar 5\% diphenyl-95\% dimethylsiloxane) was used for cholesterol analysis.

The number of calories required to utilize $1 \mathrm{~g}$ of beef was measured in a calorimeter (6400, Parr Instrument, St, Moline, IL, USA).

To analyze the myoglobin content, $2 \mathrm{~g}$ of ground beef was homogenized with $40 \mathrm{mM}$ phosphate buffer ( $\mathrm{pH}$ 6.8) and centrifuged at 5,200×g for $10 \mathrm{~min}$. The supernatant was filtered with a Whatman No. 2 filter paper. The absorbance of the filtrate was estimated at $525 \mathrm{~nm}$ and $700 \mathrm{~nm}$.

To investigate the collagen content of longissimus dorsi muscle, $4 \mathrm{~g}$ beef sample was transferred into $30 \mathrm{~mL}$ sulfuric acid solution and heated in a dry oven at $105^{\circ} \mathrm{C}$ for $16 \mathrm{~h}$. It was diluted with distilled water, homogenized and filtered with a filter paper (Whatman No.2), followed by the addition of $1 \mathrm{~mL}$ of oxidant solution to the filtrate diluted 20-fold and left at room temperature for $20 \mathrm{~min}$. It was mixed with a color reagent (Chloramin-T, Sigma-Aldrich), heated at $60^{\circ} \mathrm{C}$ for 15 min, and cooled down at room temperature. The absorbance of the final reactant was measured at $558 \mathrm{~nm}$ with a spectrophotometer (Optizen-3220UV, Mecasys, Daejeon, Korea).

Statistical analyses were carried out with the Student's t-test using SAS statistical package 9.4. Values of $p<0.05$ indicated significant differences.

\section{RESULTS AND DISCUSSION}

The formulation of the boiled feed that based on our previous study [4] is in Table 1. Agricultural by-products including rice straw that is the commonest agricultural side product in Korea was added to total mixed ration fodder. The boiled feed was prepared by addition of the same weight of water with the raw feed mixture.

There is the chemical composition of experimental feeds in Table 2. The boiled feed contained more moisture than the control feed did. The higher moisture of the boiled feed in comparison with the control feed was due to add water for it to be prepared. The fiber percentage was lower in the boiled feed than in the control feed. The fiber is sorted out as soluble and insoluble [10]. The boiled feed contained lower fiber because the soluble fiber was dissolved in water and the insoluble one was likely to be released easily into water while the feed was boiled. The advantage of the boiled feed is to make the digestion of coarse fodder easy by rumen microbes. The NDF of the boiled feed was dissolved more than twice of the control feed in rumen [6]. It seems to cause the silica-lignincellulose bond of rice straw to be loosen and/or break that the boiled feed was prepared to boil it for hours.

The fatty acid composition of beef affects the meat quality and determines its nutritional value, flavor, and expiration date [11]. We investigated the effect of boiled feed on the fatty acids composition of Hanwoo steer's longissimus dorsi muscle. The boiled feed group contained higher levels of palmitoleic acid, oleic acid, and arachidonic acid than the control group but lower levels of stearic acid, linoleic acid, and eicosenoic acid ( $p<0.05$; Table 3). Hanwoo meat contains higher levels of oleic acid compared with the other cattles [12] and Hanwoo steer meat contains higher levels of oleic acid, stearic acid, and palmitoleic acid compared with different species of cattle [12-15]. Intake of boiled feed increased the levels of oleic acid and palmitoleic acids in the steers' longissimus dorsi and improved the Hanwoo steer's characteristics. The supply of the boiled feed is the higher levels of unsaturated fatty acids including monounsaturated fatty acids in Hanwoo steer's longissimus dorsi in comparison of the control feed $(p<0.05)$. The higher the beef grade, the higher 
Table 3. Fatty acids composition of longissimus dorsi muscle of Hanwoo steers by boiled feed

\begin{tabular}{|c|c|c|c|}
\hline Items & Control (\%) & Boiled feed (\%) & $p$-value \\
\hline Myristic acid $\left(\mathrm{c}_{14: 0}\right)$ & $2.86 \pm 0.08$ & $3.01 \pm 0.09$ & 0.249 \\
\hline Palmitic acid $\left(\mathrm{c}_{16: 0}\right)$ & $27.61 \pm 0.12$ & $26.86 \pm 0.31$ & 0.090 \\
\hline Palmitoleic acid $\left(\mathrm{c}_{16: \mathrm{ln} 7}\right)$ & $3.60 \pm 0.30^{b}$ & $4.47 \pm 0.21^{a}$ & 0.031 \\
\hline Stearic acid $\left(\mathrm{C}_{18: 0}\right)$ & $13.04 \pm 0.70^{\mathrm{a}}$ & $11.15 \pm 0.32^{b}$ & 0.015 \\
\hline Oleic acid $\left(\mathrm{C}_{18: \ln 9}\right)$ & $49.93 \pm 0.57^{b}$ & $52.11 \pm 0.46^{\mathrm{a}}$ & 0.011 \\
\hline Vaccenic acid $\left(\mathrm{C}_{18: \ln 7}\right)$ & ND & ND & - \\
\hline Linoleic acid $\left(\mathrm{c}_{18: 2 n 6}\right)$ & $2.11 \pm 0.17^{\mathrm{a}}$ & $1.64 \pm 0.11^{b}$ & 0.030 \\
\hline Y-Linolenic acid $\left(\mathrm{c}_{18: 3 n \sigma}\right)$ & $0.04 \pm 0.00$ & $0.05 \pm 0.00$ & 0.810 \\
\hline Linolenic acid $\left(\mathrm{c}_{18: 3 n 3}\right)$ & $0.07 \pm 0.01$ & $0.07 \pm 0.01$ & 0.582 \\
\hline Eicosenoic acid $\left(\mathrm{C}_{20: \mathrm{n} n}\right)$ & $0.63 \pm 0.04^{\mathrm{a}}$ & $0.51 \pm 0.02^{b}$ & 0.011 \\
\hline Arachidonic acid $\left(\mathrm{C}_{20: 4 n 6}\right)$ & $0.11 \pm 0.01^{b}$ & $0.14 \pm 0.01^{\mathrm{a}}$ & 0.042 \\
\hline Saturated fatty acids (SFA) & $43.5 \pm 0.69^{\mathrm{a}}$ & $41.0 \pm 0.51^{b}$ & 0.011 \\
\hline Unsaturated fatty acids (UFA) & $56.5 \pm 0.69^{b}$ & $59.0 \pm 0.51^{a}$ & 0.011 \\
\hline Monounsaturated fatty acid (MUFA) & $54.2 \pm 0.85^{b}$ & $57.1 \pm 0.52^{\mathrm{a}}$ & 0.008 \\
\hline Polyunsaturated fatty acids (PUFA) & $2.33 \pm 0.18^{\mathrm{a}}$ & $1.89 \pm 0.12^{b}$ & 0.052 \\
\hline n3 & $0.07 \pm 0.01$ & $0.07 \pm 0.01$ & 0.582 \\
\hline n6 & $2.26 \pm 0.18^{\mathrm{a}}$ & $1.83 \pm 0.11^{b}$ & 0.047 \\
\hline MUFA/SFA & $1.25 \pm 0.04^{b}$ & $1.40 \pm 0.03^{\mathrm{a}}$ & 0.011 \\
\hline PUFA/SFA & $0.05 \pm 0.00$ & $0.05 \pm 0.00$ & 0.144 \\
\hline \multicolumn{4}{|l|}{ Means \pm SEM } \\
\hline \multicolumn{4}{|l|}{ Each sample repeated 3 times with triple. } \\
\hline Means with different superscripts in the s & Icf & & \\
\hline
\end{tabular}

was the level of oleic acid and unsaturated fatty acids including monounsaturated fatty acids in the beef. Conversely, the lower the beef grade, the higher was the level of linoleic acid, polyunsaturated fatty acids and saturated fatty acids in the beef [16-18]. The supply of the boiled feed is expected to promote safe beef production with reduced content of saturated fatty acids in addition to enhanced beef quality.

Meat is a nutritionally important source of essential amino acids and protein. Also, specific amino acids enhance the palatability and flavor of meat. The free amino acid content of the steer's longissimus dorsi muscle following supply of boiled feed showed no difference between control and boiled feed groups (Table 4). The boiled feed did not affect the free amino acid content of the steer's longissimus dorsi muscle. According to the previous study, muscle mass of Hanwoo fed with boiled feed increased [4], but muscle's major proteins are composed of skeletal muscle proteins and sarcoplasmic proteins [19] Thus, unlike the fatty acid composition, which is directly affected by the feeding effect of feed [20], the amino acid composition of the same muscle is considered to have little effect from feeding.

Inosine 5'-monophosphate (IMP), inosine and hypoxanthine are nucleic acid-related compounds, which are generated by adenosine triphosphate dissolution in the muscle after slaughter [21]. These nucleic acids affect the palatability of meat [22-24]. The nucleic acid content of the steer's longissimus dorsi muscle following consumption of boiled feed showed no difference between the control and the boiled feed groups (Table 5). The boiled feed did not affect the nucleic acid content of the longissimus dorsi muscle.

Beef contains an abundance of minerals as well as protein $[25,26]$. We investigated the effects of boiled feed on the mineral contents of Hanwoo steer's longissimus dorsi muscle. The boiled feed group showed higher levels of $\mathrm{Fe}^{2+}$ and $\mathrm{Mn}^{2+}$ ions in the longissimus dorsi muscle than the control 
Table 4. Free amino acids (FAA) compositions of longissimus dorsi muscle of Hanwoo steers by boiled feed

\begin{tabular}{lccc}
\hline \multicolumn{1}{c}{ Items } & Control $(\mathbf{m g} / \mathbf{1 0 0} \mathbf{g})$ & Boiled feed $(\mathbf{m g} / \mathbf{1 0 0} \mathbf{g})$ & $\boldsymbol{p}$-value \\
\hline Glycine (Gly) & $0.25 \pm 0.06$ & $0.18 \pm 0.02$ & 0.221 \\
Alanine (Ala) & $20.62 \pm 1.50$ & $21.63 \pm 0.71$ & 0.503 \\
Serine (Ser) & $2.21 \pm 0.18$ & $2.31 \pm 0.09$ & 0.574 \\
Proline (Pro) & $1.76 \pm 0.17$ & $2.12 \pm 0.16$ & 0.170 \\
Valine (Val) & $3.36 \pm 0.38$ & $3.96 \pm 0.21$ & 0.150 \\
Threonine (Thr) & $1.98 \pm 0.16$ & $2.05 \pm 0.11$ & 0.733 \\
Leucine (Leu) & $2.84 \pm 0.38$ & $3.64 \pm 0.40$ & 0.201 \\
Isoleucine (Ile) & $0.57 \pm 0.16$ & $0.68 \pm 0.13$ & 0.593 \\
Aspartic acid (Asp) & $0.53 \pm 0.00$ & $0.53 \pm 0.00$ & - \\
Lysine (Lys) & $3.21 \pm 0.31$ & $3.27 \pm 0.14$ & 0.851 \\
Glutamic acid (Glu) & $1.62 \pm 0.20$ & $2.26 \pm 0.27$ & 0.111 \\
Methionine (Met) & $0.45 \pm 0.03$ & $0.53 \pm 0.06$ & 0.294 \\
Histidine (His) & $2.17 \pm 0.11$ & $2.14 \pm 0.10$ & 0.843 \\
Phenylalanine (Phe) & $0.99 \pm 0.09$ & $1.25 \pm 0.15$ & 0.212 \\
Arginine (Arg) & $4.35 \pm 0.47$ & $4.00 \pm 0.15$ & 0.408 \\
Tyrosine (Tyr) & $2.35 \pm 0.08$ & $2.57 \pm 0.10$ & 0.156 \\
Cystine (Cys-cys) & $0.73 \pm 0.00$ & $0.73 \pm 0.00$ & - \\
\hline
\end{tabular}

Means \pm SEM.

Each sample repeated 3 times with triple.

Table 5. Nucleotide-related compounds of longissimus dorsi muscle of Hanwoo steers by boiled feed

\begin{tabular}{lccc}
\hline \multicolumn{1}{c}{ Items } & Control (umol/g) & Boiled feed (umol/g) & $p$-value \\
\hline Hypoxanthine & $0.10 \pm 0.01$ & $0.11 \pm 0.01$ & 0.558 \\
Uridine & $0.03 \pm 0.00$ & $0.03 \pm 0.00$ & 0.633 \\
Inosine & $0.30 \pm 0.02$ & $0.28 \pm 0.02$ & 0.451 \\
AMP & $0.12 \pm 0.00$ & $0.12 \pm 0.00$ & 0.792 \\
GMP & $0.34 \pm 0.00$ & $0.32 \pm 0.01$ & 0.068 \\
IMP & $3.22 \pm 0.20$ & $3.09 \pm 0.12$ & 0.552 \\
ADP & $0.13 \pm 0.00$ & $0.13 \pm 0.02$ & 0.837 \\
\hline
\end{tabular}

Means \pm SEM.

Each sample repeated 3 times with triple.

AMP, adenosine monophosphate; GMP, guanosine monophosphate; IMP, inosine monophosphate; ADP, adenosine diphosphate.

group $(p<0.05)$, but no differences in the levels of other minerals (Table 6). Iron deficiency is widespread in the world [27]. Iron deficiency causes anemia and adversely affects tissues including the central nervous system [28]. Manganese plays an important physiological role in the central nervous system, bone and metabolic activities [29]. Minerals are required in the human diet, and beef is an excellent source of minerals [30]. The boiled feed intake increased the levels of $\mathrm{Fe}^{2+}$ and $\mathrm{Mn}^{2+}$ ions in the steer's longissimus dorsi muscle.

Cholesterol is a structural component of the biological membrane and maintains the fluidity of cell membrane [31]. However, the excessive intake of cholesterol triggers atherosclerosis [32]. Myoglobin contributes to the taste and color of beef, which are crucial for consumer acceptance [33]. The content of collagen, the main protein of connective tissue, affects the chewiness of meat [34-37]. The cholesterol level in the longissimus dorsi muscle of steers in the boiled feed group was $63.8 \mathrm{mg} / 100 \mathrm{~g}$ compared with $40.6 \mathrm{mg} / 100 \mathrm{~g}$ in the control group $(p<0.001$; Table 7$)$. This result 
Table 6. Mineral contents of longissimus dorsi muscle of Hanwoo steers by boiled feed

\begin{tabular}{cccc}
\hline Items & Control (Unit: $\mathbf{~ m g} / \mathbf{k g})$ & Boiled feed (Unit: $\mathbf{~ m g} / \mathbf{k g})$ & $\boldsymbol{p}$-value \\
\hline $\mathrm{Ca}$ & $90.16 \pm 4.82$ & $91.22 \pm 7.65$ & 0.922 \\
$\mathrm{Mg}$ & $195.52 \pm 5.62$ & $197.27 \pm 2.41$ & 0.745 \\
$\mathrm{Fe}$ & $20.43 \pm 0.82^{\mathrm{b}}$ & $29.54 \pm 2.24^{\mathrm{a}}$ & 0.009 \\
$\mathrm{~K}$ & $2,859.72 \pm 119.37$ & $2,964.53 \pm 58.44$ & 0.391 \\
$\mathrm{P}$ & $1,577.85 \pm 36.31$ & $1,562.59 \pm 20.81$ & 0.699 \\
$\mathrm{Na}$ & $717.14 \pm 18.74$ & $671.64 \pm 17.53$ & 0.114 \\
$\mathrm{Cu}$ & $1.49 \pm 0.17$ & $1.71 \pm 0.19$ & 0.436 \\
$\mathrm{Mn}$ & $0.21 \pm 0.04^{\mathrm{b}}$ & $0.52 \pm 0.10^{\mathrm{a}}$ & 0.037 \\
$\mathrm{Zn}$ & $41.26 \pm 3.88$ & $42.01 \pm 1.70$ & 0.084 \\
\hline
\end{tabular}

Means \pm SEM.

Each sample repeated 3 times with triple.

${ }^{a, b}$ Means with different superscripts in the same row differ significantly $(p<0.05)$.

Table 7. Total cholesterol, calorie, myoglobin and collagen contents of longissimus dorsi muscle of Hanwoo steers by boiled feed

\begin{tabular}{lccc}
\hline \multicolumn{1}{c}{ Items } & Control & Boiled feed & $p$-value \\
\hline Cholesterol $(\mathrm{mg} / 100 \mathrm{~g})$ & $40.58 \pm 1.99^{\mathrm{b}}$ & $63.84 \pm 1.27^{\mathrm{a}}$ & $0.001<$ \\
Calorie $(\mathrm{cal} / \mathrm{g})$ & $2,675.17 \pm 88.23$ & $2,789.00 \pm 79.72$ & 0.374 \\
Myoglobin $(\mathrm{mg} / \mathrm{g})$ & $4.94 \pm 0.24$ & $5.42 \pm 0.15$ & 0.095 \\
Collagen $(\mathrm{g} / 100 \mathrm{~g})$ & $0.47 \pm 0.06$ & $0.47 \pm 0.04$ & 1.000 \\
\hline
\end{tabular}

Means \pm SEM.

Each sample repeated 3 times with triple.

${ }^{a, b}$ Means with different superscripts in the same row differ significantly $(p<0.05)$.

is within the range of cholesterol content in meat of approximately 30-120 mg per $100 \mathrm{~g}$ [38,39]. No significant differences were found in the calorie, myoglobin and collagen composition of the beef. Intake of boiled feed increased the cholesterol content but did not affect the caloric, myoglobin or collagen contents.

While the treatment with boiled feed does not influence the most of trace substance content, the levels of oleic acid, unsaturated fatty acids, $\mathrm{Fe}^{2+}$ and $\mathrm{Mn}^{2+}$ can be optimized to produce a high quality of beef as well as to cut production costs.

\section{REFERENCES}

1. Choi KC, Kim WH, Ilavenil S. Effect of feeding whole crop barley silage on growth performance, carcass trait and meat quality of Hanwoo steer. In: International Grassland Congress Proceedings; 2020; New Delhi, India.

2. Chung KY, Lee SH, Cho SH, Kwon EG, Lee JH. Current situation and future prospects for beef production in South Korea: a review. Asian-Australas J Anim Sci. 2018;31:951-60. https:// doi.org/10.5713/ajas.18.0187

3. Kim JJ, Yoon JY, Kim JY, Park JW. Market structure and performance analysis of the imported processing industries: focusing on the feed industries (Year 2/2). Naju, Korea: Korea Rural Economic Institute; 2018. Report No.: R825.

4. Choi JS, Jeong JT, Lee JK, Choi YS, Jung MO, Choi YI. Effect of boiled feed on carcass characteristics of Hanwoo steers. Bull Anim Biotech. 2017;9:33-7.

5. Uhm DK. Boil apparatus of feed mixing for cattle food. Korea Patent KR100779328B1, 2007 
Nov 28.

6. Zhang H, Lee Y, Nogoy K, Jung M, Park S, Choi S. Effect of boiled feed on in situ effective degradability by rumen microbes. Bull Anim Biotech. 2017;9:25-32.

7. AOAC [Association of Official Analytical Chemists] International. Official methods of analysis of AOAC International. 17th ed. Gaithersburg, MD; AOAC International; 2000.

8. Van Soest PJ, Robertson JB, Lewis BA. Methods for dietary fiber, neutral detergent fiber, and nonstarch polysaccharides in relation to animal nutrition. J Dairy Sci. 1991;74:3583-97. https:// doi.org/10.3168/jds.S0022-0302(91)78551-2

9. Folch J, Lees M, Sloane-Stanley GH. A simple method for the isolation and purification of total lipids from animal tissues. J Biol Chem. 1956;226:497-509.

10. McRorie JW, McKeown NM. Understanding the physics of functional fibers in the gastrointestinal tract: an evidence-based approach to resolving enduring misconceptions about insoluble and soluble fiber. J Acad Nutr Diet. 2017;117:251-64. https://doi.org/10.1016/ j.jand.2016.09.021

11. Wood J D, Richardson RI, Nute GR, Fisher AV, Campo MM, Kasapidou E, et al. Effects of fatty acids on meat quality: a review. Meat Sci. 2004;66:21-32. https://doi.org/10.1016/S03091740(03)00022-6

12. Cho SH, Kim JH, Seong PN, Cho YM, Chung WT, Park BY, et al. Physico-chemical meat quality properties and nutritional composition of Hanwoo steer beef with 1++ quality grade. Korean J Food Anim Resour. 2008;28:422-30. https://doi.org/10.5851/kosfa.2008.28.4.422

13. Cho SH, Park BY, Kim JH, Hwang IH, Lee JM. Fatty acid profiles and sensory properties of longissimus dorsi, triceps brachii, and semimembranosus muscles from Korean Hanwoo and Australian Angus beef. Asian-Australas J Anim Sci. 2005;18:1786-93. https://doi.org/10.5713/ ajas. 2005.1786

14. Cho SH, Kang GH, Seong PN, Park BY, Jung SG, Kang SM, et al. 2011. Meat quality and nutritional properties of Hanwoo and imported New Zealand beef. Korean J Food Sci Anim Resour. 2011;31:935-43. https://doi.org/10.5851/kosfa.2011.31.6.935

15. Lee SH, Kim CN, Ko KB, Park SP, Kim HK, Kim JM, et al. Comparisons of beef fatty acid and amino acid characteristics between Jeju black cattle, Hanwoo, and Wagyu breeds. Korean J Food Sci Anim Resour. 2019;39:402-9. https://doi.org/10.5851/kosfa.2019.e33

16. Lee YJ, Kim CJ, Kim JH, Park BY, Seong PN, Kang GH, et al. Comparison of fatty acid composition of Hanwoo beef by different quality grades and cuts. Korean J Food Sci Anim Resour. 2010;30:110-9. https://doi.org/10.5851/kosfa.2010.30.1.110

17. Hwang YH, Joo ST. Fatty acid profiles of ten muscles from high and low marbled (quality grade 1++ and 2) Hanwoo steers. Korean J Food Sci Anim Rour. 2016;36:679-88. https://doi. org/10.5851/kosfa.2016.36.5.679

18. Joo ST, Joo SH, Hwang YH. The relationships between muscle fiber characteristics, intramuscular fat content, and fatty acid compositions in M. longissimus lumborum of Hanwoo steers. Korean J Food Sci Anim Rour. 2017;37:780-6. https://doi.org/10.5851/kosfa.2017.37.5.780

19. Kim GD, Lee SY, Jung EY, Song S, Hur SJ. Quantitative changes in peptides derived from proteins in beef tenderloin (psoas major muscle) and striploin (longissimus lumborum muscle) during cold storage. Food Chem. 2021;338:15. https://doi.org/10.1016/j.foodchem.2020.128029

20. Rule DC, Busboom JR, Kercher CJ. Effect of dietary canola on fatty acid composition of bovine adipose tissue, muscle, kidney, and liver. J Anim Sci. 1994;72:2735-44. https://doi. org/10.2527/1994.72102735x

21. MacLeod G. The flavour of beef. In Shahidi F, editor. Flavor of meat and meat products. Bos- 
ton, MA: Springer; 1994. p. 4-37.

22. Batlle N, Aristoy MC, Toldrá F. ATP metabolites during aging of exudative and nonexudative pork meats. J Food Sci. 2001;66:68-71. https://doi.org/10.1111/j.1365-2621.2001.tb15583.x

23. Li X, Amadou I, Zhou GY, Qian LY, Zhang JL, Wang DL, et al. 2020. Flavor components comparison between the neck meat of donkey, swine, bovine, and sheep. Food Sci Anim Resour. 2020;40:527-40. https://doi.org/10.5851/kosfa.2020.e30

24. Webb MJ, Pendell DP, Harty AA, Salverson RR, Underwood KR, Olson KC, et al. Identifying consumer preference for beef raised with different production systems. In: South Dakota State University Beef Day 2020 Summary Publication. Brookings, SD: South Dakota State University; 2020. p. 144-9.

25. Bodwell CE, Anderson BA. 8-Nutritional composition and value of meat products. Muscle as Food. 1986. 321-69. https://doi.org/10.1016/B978-0-12-084190-5.50013-8

26. Garmyn AJ, Hilton GG, Mateescu RG, Morgan JB, Reecy JM, Tait RG, et al. Estimation of relationships between mineral concentration and fatty acid composition of longissimus muscle and beef palatability traits. J Anim Sci. 2011;89:2849-58. https://doi.org/10.2527/jas.20103497

27. Brabin BJ, Hakimi M, Pelletier D. An analysis of anemia and pregnancy-related maternal mortality. J Nutr. 2001;131:604S-15S. https://doi.org/10.1093/jn/131.2.604S

28. Schümann K, Ettle T, Szegner B, Elsenhans B, Solomons NW. On risks and benefits of iron supplementation recommendations for iron intake revisited. J Trace Elem Med Biol. 2007;21:147-68. https://doi.org/10.1016/j.jtemb.2007.06.002

29. Das S, Khatua K, Rakshit A, Carmona A, Sarkar A, Bakthavatsalam S, et al. Emerging chemical tools and techniques for tracking biological manganese. Dalton Trans. 2019;48:7047-61. https://doi.org/10.1039/C9DT00508K

30. Duan QJ, Reecy JM, Tait R, Schoonmaker JP, Beitz DC, Eenennam van A, et al. Phenotypic variation of mineral contents in beef. Fed Am Soc Exp Biol J. 2009;23:LB412

31. Yeagle PL. Cholesterol and the cell membrane. Biochim Biophys Acta Rev Biomembr. 1985; 822:267-87. https://doi.org/10.1016/0304-4157(85)90011-5

32. Nes, WD. Biosynthesis of cholesterol and other sterols. Chem Rev. 2011;111:6423-51. https:// doi.org/10.1021/cr200021m

33. Siegrist M, Sütterlin B. Importance of perceived naturalness for acceptance of food additives and cultured meat. Appetite. 2017;113:320-6. https://doi.org/10.1016/j.appet.2017.03.019

34. Maiorano G, Filetti F, Salvatori G, Gambacorta M, Bellitti A, Oriani G. Growth, slaughter and intra-muscular collagen characteristics in Garganica kids. Small Rumin Res. 2001;39:289-94. https://doi.org/10.1016/S0921-4488(00)00207-8

35. Lee YJ, Kim CJ, Park BY, Seong PN, Kim JH, Kang GH, et al. Warner-Bratzler shear force, sarcomere length, total collagen contents and sensory characteristics of Hanwoo beef (Korean native cattle) quality grade. Korean J Food Sci Anim Resour. 2009;29:726-35. https://doi. org/10.5851/kosfa.2009.29.6.726

36. Christensen M, Ertbjerg P, Failla S, Sañudo C, Richardson RI, Nute GR, et al. Relationship between collagen characteristics, lipid content and raw and cooked texture of meat from young bulls of fifteen European breeds. Meat Sci. 2011;87:61-5. https://doi.org/10.1016/j.meatsci.2010.09.003

37. Dashdorj D,Uddin MN, Aguayo D, Ochirbat Ch, Lee JS, Hwang IH. Collagen types of Hanwoo beef in relation to texture properties properties of individual muscles. In: Troy D, McDonnell C, Hinds L, Kerry J, editors. 63rd International Congress of Meat Science and Technology; 2017; Cork, Ireland. 
38. Almeida JCD, Perassolo MS, Camargo JL, Bragagnolo N, Gross JL. Fatty acid composition and cholesterol content of beef and chicken meat in Southern Brazil. Rev Bras Cienc Farm. 2006;42:109-17. https://doi.org/10.1590/S1516-93322006000100012

39. Choi CB, Shin HU, Lee SO, Kim SI, Jung KK, Choi CW, et al. Comparison of cholesterol contents and fatty acid composition in M. longissimus of Hanwoo, Angus and Wagyu crossbred steers. J Anim Sci Technol. 2008;50:519-26. https://doi.org/10.5187/JAST.2008.50.4.519 